\title{
AKIBAT HUKUM KREDITOR PEMEGANG HAK TANGGUNGAN TERHADAP OBYEK HAK TANGGUNGAN YANG DINYATAKAN GUGUR DEMI HUKUM BERDASARKAN PUTUSAN PENGADILAN
}

\author{
Emil Cahyo Prasojo \\ Magister Kenotariatan, Fakultas Hukum, Universitas Narotama Surabaya \\ Email : emilcahyo2018@gmail.com \\ Ghansham Anand \\ Magister Kenotariatan, Fakultas Hukum, Universitas Narotama Surabaya \\ Email : gansam_anand@ymail.com
}

\begin{abstract}
The establishment of mortgage insurance agency through the regulation No. 4, 1996 Concerning the Right of Land and Land-Related Objects (UUHT) aims to accommodate the needs of bank as the financial institution to secure credit transactions that arechanneled to the community. Mortgage provides primary position for certain creditorsin case of default by the debtor. Moreover, there is legal vacuum within UUHT mainly about legal protection for creditor as the right holder of mortgage when it is canceled by the court. The present study tries to elaborate coupled with examine further about legal consequences of creditor as rights holder toward mortgage that is aborted by the court and legal protection for creditor concerning abortion of the mortgage. The method used in the present study is a normative legal research, namely legal research which is conducted by examining the library materials or secondary law while in finding and collecting the data is done by two approaches, namely the law and conceptual approaches. The present study concludes that the cancelation of mortgage by the court stimulates alteration position of creditor in which at the beginning creditor holds position as preferment creditor into concurrent creditor in which the settlement concerning fulfillment of receivables can be preceded.Legal protection for creditor in regard to the cancelation of mortgage can be achieved in two ways: (1) preventive way through agreement by adding clause concerning replacement of the mortgage with other mortgage; (2) repressive way by filling a lawsuit to the court which is followed with application for confiscation replacement of collateral against property of the party that is conducting default.
\end{abstract}

Keywords: Mortgage Rights, Warranty Object, Void ab Initio

\begin{abstract}
Abstrak
Lahirnya lembaga jaminan hak tanggungan melalui diundangkannya Undang-undang Nomor 4 Tahun 1996 Tentang Hak Tanggungan Atas Tanah Beserta Benda-Benda Yang Berkaitan Dengan Tanah (UUHT) bertujuan untuk mengakomodasi kebutuhan lembaga perbankan sebagai upaya mengamankan kredit yang disalurkan kepada masyarakat. Hak Tanggungan memberikan kedudukan yang diutamakan kepada kreditur tertentu terhadap kreditur-kreditur yang lain apabila terjadi wanprestasi oleh debitur. Namun demikian masih terdapat kekosongan hukum dalam UUHT terkait perlindungan hukum bagi kreditur apabila terjadi obyek hak tanggungan dinyatakan gugur demi hukum berdasarkan putusan pengadilan. Penulis dalam penelitian ini ingin menelaah dan menganalisa lebih lanjut tentang akibat hukum bagi kreditur setelah obyek Hak Tanggungan dinya-
\end{abstract}


takan gugur berdasarkan putusan pengadilan dan bentuk perlindungan hukum bagi kreditur atas gugurnya obyek jaminan hak tanggungan.Metode penelitian yang digunakan adalah penelitian hukum normatif, yaitu penelitian hukum yang dilakukan dengan cara meneliti bahan pustaka atau bahan hukum sekunder sedangkan pendekatan masalah dilakukan dengan menggunakan pendekatan undang-undang dan pendekatan konseptual. Hasil penelitian menunjukkan bahwa gugurnya obyek Hak Tanggungan oleh putusan pengadilan mengakibatkan berubahnya posisi Kreditur yang semula berkedudukan sebagai Kreditur preferent menjadi kreditur konkuren yang dalam pemenuhan piutangnya tidak dapat didahulukan pelunasannya. Perlindungan hukum bagi Kreditur atas hapusnya obyek hak tanggungan dapat diperoleh secara preventif melalui perjanjian dengan memasukkan klausul mengenai penggantian obyek jaminan dengan obyek lainnya dan secara represif dengan cara mengajukan gugat ke pengadilan bersamaan dengan permohonan peletakan sita jaminan terhadap harta pihak yang melakukan wanprestasi.

Kata Kunci : Hak Tanggungan, Obyek Jaminan, Batal Demi Hukum

\section{PENDAHULUAN}

\subsection{Latar Belakang}

Kegiatan pembangunan ekonomi memerlukan tersedianya dana yang salah satunya dapat diperoleh dengan mengajukan permohonan kredit yang diberikan perbankan nasional. Salah satu sumber pendanaan yang diharapkan dapat menunjang perkembangan dunia usaha adalah pendanaan dari Bank. Menurut Kasmir, bank dikenal sebagai lembaga keuangan yang kegiatan usahanya adalah menghimpun dana dari masyarakat dan menyalurkan kembali dana tersebut ke masyarakat serta memberikan jasa-jasa bank lainnya. ${ }^{1}$ Penyaluran dana tersebut dapat terjadi dalam bentuk kredit dan atau bentuk lainnya.

Penyaluran kredit kepada masyarakat sebagai pelaku usaha, selaku debitur, penuh dengan risiko kemacetan dalam pelunasannya. Agar dapat mengurangi risiko kemacetan dalam penyaluran kredit diperlukan adanya lembaga jaminan sebagai sarana pengaman. Menurut Irma Devita Purnamasari, pemberian jaminan dalam perjanjian kredit diharuskan dalam dunia perbankan konvensional karena pada dasarnya, sumber dana yang disalurkan berasal dari masyarakat atau tabungan masyarakat. Dengan demikian, dana kredit yang disalurkan harus dilakukan secara hatihati (prudent). Meskipun Kredit Tanpa Agunan (KTA), Kredit Usaha rakyat (KUR), atau kredit mikro lainnya yang diberikan kepada debitur tanpa adanya syarat agunan, pemberian kredit jenis tersebut dilakukan sangat selektif. Namun perlindungan yang berasal dari jaminan umum tersebut dirasakan belum memberikan rasa aman bagi kreditur, sehingga dalam praktik penyaluran kredit, bank memandang perlu untuk meminta jaminan khusus terutama yang bersifat kebendaan. Permintaan jaminan khusus oleh bank dalam penyaluran kredit tersebut merupakan realisasi dari prinsip kehatihatian bank sebagaimana ditentukan UU Perbankan. Jaminan kebendaan mempunyai posisi paling dominan dan dianggap strategis dalam penyaluran kredit bank. Jaminan kebendaan yang paling banyak diminta oleh bank adalah berupa

1 Kasmir, Pemasaran Bank, Jakarta: Prenada Media, 2005, hlm. 8-9 
tanah atau tanbah dan bangunan karena secara ekonomis tanah mempunyai prospek yang menguntungkan. ${ }^{2}$

Diundangkannya Undang-undang Nomor 4 Tahun 1996 Tentang Hak Tanggungan Atas Tanah Beserta Benda-Benda Yang Berkaitan Dengan Tanah (UUHT) dapat mengakomodasi kebutuhan lembaga perbankan sebagai upaya mengamankan kredit yang disalurkan kepada masyarakat. Di dalam Pasal 1 ayat (1) UUHT, disebutkan bahwa Hak Tanggungan adalah Hak Jaminan yang dibebankan pada hak atas tanah sebagaimana dimaksud dalam Undang-undang Nomor 5 Tahun 1960 tentang Peraturan Dasar Pokok-Pokok Agraria, berikut atau tidak berikut benda-benda lain yang merupakan satu kesatuan dengan tanah itu, untuk pelunasan utang tertentu, yang memberikan kedudukan yang diutamakan kepada kreditur tertentu terhadap kreditur-kreditur yang lain.

Pada dasarnya yang dapat membebankan suatu hak atas tanah dengan Hak Tanggungan adalah pemilik hak atas tanah itu sendiri, ketentuan sebagaimana diatur dalam Pasal 8 UUHT yang menentukan : "(1) Pemberi Hak Tanggungan adalah perseorangan atau badan hukum yang mempunyai kewenangan untuk melakukan perbuatan hukum terhadap obyek Hak Tanggungan yang bersangkutan; (2) Kewenangan untuk melakukan perbuatan hukum terhadap obyek Hak Tanggungan sebagaimana dimaksud pada ayat (1) harus ada pada pemberi Hak Tanggungan pada saat pendaftaran Hak Tanggungan dilakukan."

Apabila ternyata di kemudian hari hak atas tanah tersebut disengketakan dan pemberi Hak
Tanggungan dinyatakan bukan sebagai orang/pihak yang berhak atas tanah tersebut, yang dengan demikian akan berimplikasi pada Hak Tanggungan yang membebani hak atas tanah tersebut. Kondisi tersebut terjadi didalam putusan Mahkamah Agung Nomor 2301 K/Pdt/2007, dimana Penggugat dan Tergugat I awalnya adalah pasangan suami istri, yang pada saat perkawinan masih berlangsung keduanya membeli sebuah tanah. Pada saat perceraian, keduanya belum membagi harta bersama di antara mereka. Tergugat I kemudian menjual tanah tersebut kepada Tergugat II dan setelah jual beli dilaksanakan Tergugat II kemudian menjaminkan tanah tersebut kepada bank. Dalam perkara ini, hakim memutuskan bahwa sertifikat Hak Tanggungan tidak mempunyai kekuatan hukum.

\subsection{Rumusan Masalah}

1. Apakah akibat hukum bagi kreditur setelah obyek Hak Tanggungan dinyatakan gugur berdasarkan putusan pengadilan?

2. Apa Perlindungan Hukum Bagi Kreditur Atas Gugurnya Obyek Jaminan Hak Tanggungan?

\subsection{Metode Penelitian}

Penelitian ini menggunakan metode penelitian hukum normatif yang dilakukan untuk mencari pemecahan masalah atas permasalahan hukum yang ada. Pendekatan penelitian yang digunakan adalah pendekatan undang-undang (statute approach) dan pendekatan konseptual (conceptual approach).

2 Irma Devita Purnamasari, Hukum Jaminan Perbankan, Bandung: Mizan Pustaka, 2011, hlm. 18 


\section{PEMBAHASAN}

2.1. Akibat Hukum Bagi Kreditur Atas Putusan Pengadilan Yang Menyatakan Obyek Hak Tanggungan Gugur

Jaminan merupakan terjemahan dari bahasa Belanda yaitu zekerheid atau cautie. Zekerheid atau cautie mencakup secara umum cara-cara kreditur menjamin dipenuhinya tagihannya, disamping pertanggung jawab umum debitur terhadap barang-barangnya. Secara umum pengertian jaminan dapat dimaknai dengan "menjamin dipenuhinya kewajiban yang dapat dinilai dengan uang yang timbul dari suatu perikatan hukum. ${ }^{3}$ Oleh karena itu, hukum jaminan erat sekali kaitannya dengan hukum benda. ${ }^{4}$

Djuhaendah Hasan memberikan pengertian Jaminan sebagai sarana perlindungan bagi keamanan kreditur yaitu kepastian akan pelunasan hutang debitur atas pelaksanaan suatu prestasi oleh debitur atau oleh penjamin debitur. ${ }^{5}$ Menurut Rachmadi Usman, jaminan sebagai suatu sarana perlindungan keamanan kreditur, yaitu kepastian akan pelunasan utang debitur atas pelaksanaan suatu prestasi oleh debitur atau oleh penjamin debitur. ${ }^{6}$ Pendapat lain dikemukakan oleh R. Subekti, yang menyatakan bahwa pemberian jaminan kebendaan berupa menyendirikan suatu bagian dari kekayaan seorang pemberi jaminan dan menyediakannya untuk pemenuhan kewajiban atau hutang debitur. ${ }^{7}$

Peraturan yang berlaku di Indonesia secara umum telah memberikan pengaman kepada kreditur dalam menyalurkan kredit kepada debitur, yakni dengan memberikan jaminan umum menurut Pasal 1131 dan 1132 Burgerlijk Wetboek (selanjutnya disebut BW), yang menentukan bahwa semua harta kekayaan (kebendaan) debitur baik bergerak maupun tidak bergerak, yang sudah ada maupun yang akan ada menjadi jaminan atas seluruh perikatannya dengan kreditur. Apabila terjadi wanprestasi maka seluruh harta benda debitur dijual lelang dan dibagi-bagi menurut besar kecilnya piutang masing-masing kreditur.

Pasal 1131 BW menegaskan : "Segala kebendaan si berhutang, baik yang bergerak maupun tidak bergerak, baik yang sudah ada maupun yang baru akan ada dikemudian hari, menjadi tanggungan untuk segala perikatannya perseorangan". Selanjutnya ditegaskan dalam Pasal 1132 BW : "kebendaan tersebut menjadi jaminan bersama-sama bagi semua orang yang mengutangkan padanya pendapatan penjualan benda-benda itu dibagi menurutkeseimbangan, yaitu menurut besar kecil piutang masing-masing, kecuali apabila diantara para berpiutang ada alasan-alasan yang sah untuk didahulukan".

Menurut J. Satrio dari Pasal 1131 BW dapat disimpulkan bahwa : 1) Seorang kreditur boleh mengambil pelunasan dari setiap bagian dari harta kekayaan debitur; 2) Setiap bagian Kekayaan debitur dapat dijual guna pelunasan tagihan kreditur; 3) Hak tagihan kreditur hanya dijamin dengan harta benda debitur saja, tidak dengan "persoon debitur". 8

3 Herowati Poesoko, Parate execcutie Obyek Hak Tanggungan (inkonsistensi, Konflik Norma dan Kesesatan Penalaran dalam UUHT), , Yogyakarta: LaksBang PRESSind, 2008, hlm. 31-32.

4 Mariam Darus Badrulzaman, Bab-bab Tentang Credietverband, Bandung: Gadai dan Fidusia, Alumni, 1987, hlm. 227-265.

5 Djuhaendah Hasan, Lembaga Jaminan Kebendaan Bagi Tanah dan Benda Lain yang Melekat pada Tanah dalam Konsepsi Penerapan Asas Pemisahan Horizontal, Bandung: Citra Aditya Bakti, 1996, hlm. 233.

Rachmadi Usman, Aspek-aspek Hukum Perbankan di Indonesia, Jakarta: Gramedia Pustaka Utama, 2001, hlm. 61.

7 R. Subekti, Jaminan-jaminan Untuk Pemberian Kredit Menurut Hukum Indonesia, Bandung: Citra Aditya Bakti, 1991, hlm. 19

J.Satrio, Hukum Jaminan,Hak Jaminan Kebendaan Hak Tanggungan, Banudng: Alumni, 1997, hlm. 34-35 
Pembagian dan pengelompokan terhadap kreditur dalam hukum perdata umum telah diatur dalam BW yang membagi kreditur menjadi macam, yaitu kreditur preferen dan kreditur konkuren. Kreditur Preferen adalah kreditur yang mempunyai hak pengambilan pelunasan terlebih dahulu daripada kreditur lain dan kreditur preferen itu tagihannya didahulukan atau diistimewakan daripada tagihan-tagihan kreditur lain. ${ }^{9}$ Sedangkan kreditur konkuren adalah kreditur bersaing yang artinya bahwa kreditur konkuren tidak mempunyai keistimewaan sehingga kedudukannya satu sama lain sama. ${ }^{10}$ Kreditur tersebut bersaing satu dengan yang lainnya untuk memperoleh pembayaran dari hasil lelang, sehingga keududukannya pun tidak diutamakan dalam pelunasan. ${ }^{11}$

Kreditur konkuren adalah kreditur yang tidak diistimewakan dan atau bukan merupakan kreditur yang diperjanjikan sebelumnya, sehingga piutang-piutang dari kreditur konkuren merupakan piutang yang masuk dalam boedel pailit apabila debitur dinyatakan pailit oleh para krediturnya. Serta pelunaaannya pun harus menunggu dari hasil sisa pelunasan atau pelelangan harta pailit dan sisa pelunasan tersebut harus dibagikan setelah sebelumnya dikurangi dengan kewajiban membayar piutang kepada para kreditur pemegang hak jaminan dan para kreditur dengan hak istimewa secara proporsional menurut perbandingan besarnya piutang masing-masing kreditur konkuren tersebut (pari passu pro rata parte)..$^{12}$

Dalam jaminan yang bersifat umum, semua kreditur mempunyai kedudukan yang sama tehadap kreditur-kreditur lainnya, tidak ada kreditur yang diutamakan atau diistimewakan dari krediturkreditur lainnya. Pelunasan utangnya dibagi secara seimbang berdasarkan besar kecilnya jumlah tagihan masing-masing kreditur dibanding jumlah keseluruhan utang debitur.

Jaminan berdasarkan jenisnya dibedakan menjadi jaminan perorangan dan jaminan kebendaan. Jaminan perorangan (borgtoch/ personal guarantee) adalah jaminan berupa pernyataan kesanggupan yang diberikan oleh seorang Pihak Ketiga guna menjamin pemenuhan kewajiban-kewajiban debitur kepada kreditur, apabila debitur yang bersangkutan cidera janji (wanprestasi). Sedangkan jaminan kebendaan (zakelijke zekerhed/ security right in rem)adalah jaminan berupa harta kekayaan dengan cara pemisahan bagian dari harta kekayaan baik si debitur maupun pihak ketiga, guna menjamin pemenuhan kewajiban-kewajiban debitur yang bersangkutan cidera janji (wanprestasi). ${ }^{13}$ Jaminan yang bersifat kebendaan dilembagakan dalam bentuk hipotek, hak tanggungan, fidusia, dan gadai. Jaminan kebendaan sendiri adalah tindakan penjaminan oleh kreditur terhadap debiturnya guna memenuhi kewajiban dari pihak debitur. ${ }^{14}$

\section{Mengenai Hak Tanggungan, pada} dasarnya adalah hak jaminan yang dibebankan pada hak atas tanah. Namun, pada kenyataannya seringkali terdapat benda-benda berupa bangunan, tanaman dan hasil karya yang secara tetap merupakan satu kesatuan dengan tanah yang dijadikan jaminan turut pula dijaminkan.

\footnotetext{
Hatta Isnaini Wahyu Utomo, "Hukum Jaminan", Bahan Ajar, Surabaya: Fakultas Hukum Universitas Yos Sudarso, 2017, hlm. 6

10 Trisadini Prasastinah Usanti, dan Leonora Bakarbessy, Buku Referensi Hukum Perbankan Hukum Jaminan, Revka Petra Media, 2016, hlm. 26

11 Man S. Sastrawidjaja, Hukum Kepailitan dan Penundaan Kewajiban Pembayaran Utang, Bandung: Alumni, 2014, hlm. 127

12 Sutan Remy Sjahdeini, Hukum Kepailitian, Jakarta: Grafiti, 2010, hlml. 6-7

13 Herowati Poesoko, Op.Cit., hlm. 33-34.

14 Abdul R. Saliman, Hukum Bisnis Untuk Perusahaan Teori dan Contoh Kasus, Jakarta: Kencana, 2010, hlm. 22
} 
Sebagaimana diketahui bahwa Hukum Tanah Nasional didasarkan pada hukum adat, yang menggunakan asas pemisahan Horizontal, yang menjelaskan bahwa setiap perbuatan hukum mengenai hak-hak atas tanah tidak dengan sendirinya meliputi benda-benda tersebut. ${ }^{15}$

Apa yang dimaksud dengan pengertian "kedudukan yang diutamakan kepada krediturkreditur lain" tidak dijumpai di dalam penjelasan Pasal 1 tersebut, tetapi dijumpai di dalam angka 4 Penjelasan Umum UUHT yang menyebutkan bahwa yang dimaksud dengan "memberikan kedudukan diutamakan kepada kreditur tertentu terhadap kreditur-kreditur lain" ialah : "bahwa jika kreditur cidera janji, kreditur pemegang Hak Tanggungan berhak menjual melalui pelelangan umum tanah yang dijadikan jaminan menurut ketentuan peraturan perundang-undangan yang bersangkutan, dengan hak mendahulu daripada krediturkreditur yang lain. Kedudukan yang diutamakan tersebut sudah barang tentu tidak mengurangi preferensi piutang-piutang negara menurut ketentuan-ketentuan hukum yang berlaku".

Hal itu juga dapat diketahui dari ketentuan Pasal 20 ayat (1) UUHT yang intuisi dinyatakan bahwa apabila debitur cidera janji, maka:

a. Hak pemegang Hak Tanggungan pertama untuk menjual objek Hak Tanggungan sebagaimana dimaksud dalam Pasal 6, atau

b. Titel eksekutorial yang terdapat dalam sertipikat Hak Tanggungan sebagaimana dimaksud dalam Pasal 14 ayat (2),

Apabila debitur cidera janji (wanprestasi), maka kreditur tidak perlu menempuh acara gugatan perdata biasa yang memakan waktu dan biaya yang tidak sedikit. Kreditur pemegang Hak Tanggungan dapat menggunakan haknya untuk menjual obyek hak tanggungan melalui pelelangan umum. Selain melalui pelelangan umum berdasarkan Pasal 6, eksekusi obyek hak tanggungan juga dapat dilakukan dengan cara "parate executie" sebagaimana diatur dalam Pasal 224 HIR dan Pasal 158 RBg bahkan dalam hal tertentu penjualan dapat dilakukan dibawah tangan. ${ }^{16}$

Menurut Gatot Supramono, wanprestasi yang dilakukan oleh debitur tergolong sebagai kredit bermasalah, maka terdapat tiga macam perbuatan yang tergolong wanprestasi, yaitu:

1. Debitur sama sekali tidak dapat membayar angsuran kredit beserta bunganya.

2. Debitur membayar sebagian angsuran kredit beserta bunganya.

3. Debitur menggunakan kreditnya untuk kepentingan lainnya. ${ }^{17}$

Hak tanggungan pada pokoknya merupakan perjanjian yang bersifat asesoir. Menurut Sri Soedewi Masjchoen Sofwan jaminan dikonstruksikan sebagai perjanjian yang bersifat asesoir yaitu senantiasa merupakan perjanjian yang dikaitkan dengan perjanjian pokok, dan mengabdi pada perjanjian pokok. ${ }^{18}$ Pendapat serupa dikemukakan Mariam Darus Badrulzaman, yang menyatakan bahwa sifat asesoir sesuai sifat yang melekat pada hukum jaminan. Gadai dan Hipotek. Lahir dan berakhirnya penyerahan Hak Milik bergantung pada hutang pokok. Hal ini berdasar bahwa pada umumnya diakui bahwa segala sesuatu yang memperoleh dukungan akan menjadi lebih

\footnotetext{
15 Purwahid Patrik, Hukum Jaminan, Edisi Revisi dengan UUHT, Semarang: Fakultas Hukum Universitas Diponegoro, 1989, hlm. 52.

16 Boedi Harsono, Hukum Agraria Indonesia, Sejarah Pembentukan Undang-Undang Pokok Agraria, Isi dan Pelaksanaannya, Jakarta: Djambatan, 2000, hlm. 420.

17 Gatot Supramono, Perbankan dan Masalah Kredit, Jakarta: Rineka Cipta, 2009, hlm. 268.

18 Sri Soedewi Masjchoen Sofwan, Hukum Jaminan di Indonesia : Pokok-Pokok Hukum Jaminan dan Jaminan Perorangan, Yogyakarta: Liberty, 1980, hIm. 37
} 
kokoh ketimbang saat sebelumnya ketika tidak ada pendukungnya, maksudnya perjanjian utang piutang kedudukannya akan semakin kokoh manakala didukung oleh perjanjian jaminan teutama adanya perjanjian kebendaan. Begitu pula bilamana perjanjian obligatoir termasuk perjanjian kredit yang bermula sekedar memiliki sifat relatif sehingga krediturnya hanya bersifat kreditur konkuren, bilamana kemudian didukung oleh perjanjian jaminan yang memiliki sifat kebendaan, mengakibatkan kreditur yang bersangkutan berubah posisi menjadi kreditur preferen dengan hak-hak yang lebih istimewa. ${ }^{19}$

Jaminan hak tangungan ini termasuk dalam jaminan kebendaan, hal ini karena jaminan Hak Tanggungan lahir dari perjanjian yang bersifat accessoir. Menurut Sutan Remy Sjahdeni, Perjanjian Hak Tanggungan bukan merupakan perjanjian yang berdiri sendiri. Keberadaannnya adalah karena adanya perjanjian lain yang disebut perjanjian induk. Perjanjian induk bagi perjanjian Hak Tanggungan adalah perjanjian hutang piutang yang menimbulkan hutang yang dijamin, dengan kata lain perjanjian Hak Tanggungan adalah perjanjian accesoir, dan merupakan perjanjian jaminan kebendaan. ${ }^{20}$

Pada angka 8 Penjelasan Umum UUHT dinyatakan : "oleh karena Hak Tanggungan menurut sifatnya merupakan ikutan atau accessoir pada suatu piutang tertentu, yang didasarkan pada suatu perjanjian utang piutang atau perjanjian lain, maka kelahiran dan keberadaannya ditentukan oleh adanya piutang yang dijamin pelunasannya". Dengan demikian maka sesuai dengan sifat
Accecoir dari hak tanggungan tersebut untuk proses pembebanan hak tanggungan yang didahului dengan perjanjian yang menimbulkan hubungan hukum hutang piutang yang dijamin pelunasannya, yang merupakan perjanjian pokoknya. Sebagaimana tersebut dalam Pasal 10 ayat (1) UUHT yang menyatakan bahwa pemberian hak tanggungan didahului dengan janji untuk memberikan hak tanggungan sebagaimana jaminan pelunasan hutang tertentu, yang dituangkan di dalam dan merupakan bagian tidak terpisahkan dari perjanjian hutang piutang yang bersangkutan.

Pasal 8 UUHT menyatakan bahwa Pemberi Hak Tanggungan adalah orang atau badan hukum yang mempunyai kewenangan untuk melakukan perbuatan hukum terhadap obyek hak tanggungan yang bersangkutan. Berdasarkan Pasal 8 tersebut, maka Pemberi Hak Tanggungan di sini adalah pihak yang berutang atau debitur.

Berkenaan dengan hak tanggungan maka apabila ada gugatan dari pihak ketiga untuk membatalkan sertifikat hak atas tanah yang sedang dijadikan objek jaminan oleh debitur,dan kemudian atas gugatan itu oleh Pengadilan diputuskan bahwa pihak ketiga yang menggugat menjadi pemilik sah atas sertifikat hak atas tanah tersebut akan mengakibatkan hak debitur terhadap objek jaminan menjadi hapus, dimana hapusnya hak debitur terhadap objek jaminan akan mengakibatkan hapusnya hak tanggungan yang sedang berjalan

Hapusnya Hak Tanggungan sebagai perjanjian kebendaan mempunyai akibat hukum, yaitu berubahnya posisi Kreditur, yang semula berkedudukan sebagai Kreditur preferent yang

\footnotetext{
19 Mariam Darus Badrulzaman, Bab-Bab Tentang Credietverband, Gadai, Fidusia, Bandung: Alumni, 1987, hlm. 95-96.

20 Sutan Remy Sjahdeini, Hak Tanggungan - Asas-Asas, Ketentuan Pokok dan Masalah Yang Dihadapi Oleh Perbankan, Bandung: Alumni, 1999, hlm. 29.
} 
mempunyai hak kebendaan kemudian berkedudukan sebagai kreditur konkurent yang mempunyai hak perseorangan. Hak perseorangan merupakan hak yang timbul dari jaminan umum atau jaminan yang lahir dari undang-undang, sebagaimana yang tercantum dalam Pasal 1131 BW. Oleh karena itu Kreditur mempunyai persamaan hak dan persamaan kedudukan dengan Kreditur lainnya terhadap harta seorang Debitur sehingga dalam pemenuhan piutangnya tidak dapat didahulukan pembayarannya sekalipun di antara mereka ada yang mempunyai tagihan yang lahir terlebih dulu dari pada yang lain. Konkretnya seorang Kreditur tidak berhak menuntut pelunasan lebih dulu dari Kreditur yang lain

\subsection{Perlindungan Hukum Bagi Kreditur Atas Gugurnya Obyek Jaminan Hak Tanggungan}

Pada Putusan Mahkamah Agung Nomor $2301 \mathrm{~K} / \mathrm{Pdt} / 2007$ hakim telah memutuskan bahwa judex facti tidak salah menerapkan hukum atas tanah sengketa (Sertifikat Hak Milik No.130/Desa Sindangjati Gambar Situasi No.389/1973 tanggal 10 Juli 1973) karena tanah tersebut merupakan harta bersama/gono-gini milik Penggugat dan Tergugat I yang belum terbagi, namun telah dipindahtangankan/dijual oleh Tergugat I tanpa persetujuan/ sepengetahuan Penggugat. Selain itu hakim juga memutus bahwa beli yang dilakukan Tergugat I dan Tergugat II batal demi hukum serta menyatakan produk hukum yang lain yang bersumber dari dan timbul atas dasar adanya jual beli tersebut dinyatakan batal demi hukum atau tidak mempunyai kekuatan hukum.
Jual beli yang dilakukan Tergugat I dengan Tergugat II atas obyek sengketa adalah tanpa seijin atau persetujuan dari Penggugat sebagai pemilik obyek sengketa harta bersama, oleh karena itu jual beli tersebut tidak sah dikarenakan nyata-nyata dilarang oleh aturan hukum yang berlaku. Dalam Yurisprudensi Mahkamah Agung Republik Indonesia Nomor : 681 K/SIP/1975 jo Nomor : 2690 K/Pdt/1985 tanggal 19 Nopember 1986 jo. Nomor : $1851 \mathrm{~K} / \mathrm{Pdt} / 1996$ tanggal 23 Pebruari 1998 jo Nomor: 701 K/Pdt/1997 tanggal 24 Maret 1999 menyatakan : "Jual beli tanah yang merupakan harta bersama harus disetujui pihak isteri atau suami" ; "Harta bersama berupa tanah yang dijual tanpa persetujuan salah satu pihak (suami/istri) adalah tidak sah dan batal demi hukum" ; "Sertifikat tanah yang dibuat/dibalik-nama atas dasar jual beli yang tidak sah adalah cacat yuridis dan tidak mempunyai kekuatan hukum".

\section{Terputusnya persatuan harta kekayaan} karena perceraian tidak berarti bahwa harta kekayaan itu sudah dibagi. Hanya saja setelah saat itu suami atau isteri (atau para ahli waris mereka) boleh menuntut agar diadakan pemecahan dan pembagian (karena persatuan harta kekayaan merupakan milik bersama terikat, sebelum persatuan putus tidak mungkin diadakan pemecahan dan pembagian). Pada pokoknya masing masing pihak (suami dan isteri), mendapat bagian $50 \%$ dari milik bersama (boedel) itu. ${ }^{21}$

Adanya putusan tersebut diatas membawa implikasi panjang karena Tergugat II telah menjadikan tanah yang dibelinya dari Tergugat I sebagai jaminan hutang dengan dibebani Hak

21 Christian Liongan, "Penyelesaian Pembagian Harta Perkawinan Bagi WNI Keturunan Tionghoa Setelah Berlakunya UndangUndang Nomor 1 Tahun 1974 Tentang Perkawinan Di Kota Manado, Sulawesi Utara", Tesis, Program Pasca Sarjana, Semarang: Universitas Diponegoro, 2007, hlm. 61. 
Tangungan. Gugurnya obyek hak tanggungan tersebut apabila dianalisis dengan UUHT maka akan sangat berkaitan dengan ketentuan dalam Pasal 8 UUHT yang menentukan mengenai kewenangan pemberi hak tanggungan. Kewenangan untuk melakukan perbuatan hukum terhadap obyek hak tanggungan tersebut harus ada pada pemberi hak tanggungan pada saat pendaftaran hak tanggungan dilakukan, karena lahirnya hak tanggungan adalah pada saat didaftarkannya hak tanggungan, maka kewenangan untuk melakukan perbuatan hukum terhadap obyek hak tanggungan diharuskan ada pada pemberi hak tanggungan pada saat pembuatan buku tanah hak tanggungan. ${ }^{22}$

Kecakapan bertindak dalam banyak hal berhubungan dengan masalah kewenangan bertindak dalam hukum, dimana kecakapan berkaitan dengan masalah kemampuan untuk melakukan suatu tindakan/perbuatan hukum dan kewenangan berkaitan dengan kapasitas subjek hukum dalam melakukan tindakan/perbuatan hukum. ${ }^{23}$ Kewenangan pemberi hak tanggungan tersebut sangat penting untuk diperhatikan karena apabila pemberian objek hak tanggungan tidak dilakukan oleh pemiliknya, maka pemberian objek jaminan tersebut dapat menjadi batal dan selanjutnya atas akta pembebanannya juga menjadi batal demi hukum. ${ }^{24}$

Perjanjian hak tanggungan kewenangan menentukan pemberi hak tanggungan berkaitan dengan kewenangan untuk melakukan perbuatan hukum atas objek hak tanggungan, karena pemberi hak tanggungan adalah pemilik persil yang dengan sepakatnya dibebani dengan hak tanggungan sampai sejumlah hutang tertentu untuk menjamin suatu perikatan/hutang, ${ }^{25}$ sehingga yang dapat menjadi pemberi hak tanggungan adalah pemilik hak atas tanah yang dijaminkan.

Moch. Isnaeni menyatakan bahwa pada dasarnya pihak yang wenang menjaminkan suatu benda adalah pemilik, dengan pemahaman bahwa menjaminkan itu merupakan langkah awal mengasingkan benda sedangkan yang diberi wewenang untuk mengasingkan benda adalah pemilik. Dari kondisi tersebut, apabila debitur selaku pemilik benda yang dibebani jaminan ternyata wanprestasi maka benda jaminan tersebut akan dijual melalui lelang dan penjualan di muka umum tersebut dilakukan olek kreditor atas perkenan atau kuasa dari debitur selaku pemilik benda. ${ }^{26}$

Apabila terjadi pembatalan hak tanggungan maka tujuan untuk memberikan perlindungan hukum bagi kreditur pemegang hak tanggungan tidak akan tercapai, tetapi dalam praktik untuk memastikan pemilik yang sah dari suatu hak atas tanah terkadang sulit, hal ini dikarenakan pendaftaran hak atas tanah yang dianut Indonesia berdasarkan PP No.24 Tahun 1997 tentang Pendaftaran Tanah menggunakan sistem publikasi negatif yang mengandung unsur positif. Hal ini berarti sertifikat sebagai tanda bukti yang kuat atas kepemilikan suatu hak atas tanah akan tetapi tidak mutlak, sehingga pemilik terdaftar masih dapat digugat oleh orang lain yang merasa berhak. ${ }^{27}$

Purwahid Patrik, Op. Cit., hlm. 62.

23 Kartini Muljadi dan Gunawan Widjaja, Seri Hukum Harta Kekayaan: Hak Tanggungan, Jakarta: Prenada Media, 2004, hlm. 23

24 Try Widiyono, Agunan Kredit Dalam Financial Engineering, Jakarta: Ghalia Indonesia, 2009, hlm. 290

25 J. Satrio, Op.Cit., hlm. 245

26 Moch. Isnaeni, Pengantar Hukum Jaminan Kebendaan, Surabaya: Revka Petra Media, 2016, hlm. 47

27 Adrian Sutedi, Peralihan Hak Atas Tanah dan Pendaftarannya, Jakarta: Sinar Grafika, 2010, hlm. 120-122 
Mengenai kewenangan debitur dalam kasus ini untuk menjaminkan tanahnya dengan dibebani hak tanggungan sejatinya sudah dimiliki debitur, namun dengan diputuskannya batal atas jual beli sebagai dasar perolehan tanah tersebut maka segala perbuatan hukum yang lahir setelahnya menjadi batal demi hukum. Dengan dinyatakannya batal atas segala produk yang lahir dari akta jual beli tersebut tersebut tentu saja akan merugikan pihak bank sebagai pemegang Hak Tanggungan, dimana yang sebelumnya berkedudukan sebagai kreditor preferen dengan hapusnya Hak Tanggungan maka hanya akan berkedudukan sebagai kreditor konkuren. Dalam kondisi ini tentunya kreditur membutuhkan adanya suatu bentuk perlindungan hukum.

Menurut Sudikno Mertokusumo, yang dimaksud dengan hukum adalah kumpulan peraturan atau kaedah yang mempunyai isi yang bersifat umum dan normatif, umum karena berlaku bagi setiap orang dan normative karena menentukan apa yang seyogyanya dilakukan, apa yang tidak boleh dilakukan atau harus dilakukan serta menentukan bagaimana caranya melaksanakan kepatuhan pada kaedah-kaedah. ${ }^{28}$ Sehingga dengan demikian perlindungan hukum dapat dimaknai sebagai suatu perbuatan hal melindungi subjek-subjek hukum dengan peraturan perundang-undangan yang berlaku dan pelaksanaannya dapat dipaksakan dengan suatu sanksi.

Philipus M. Hadjon menyebutkan terdapat 2 macam perlindungan hukum, yaitu : a. Perlindungan Hukum Preventif yaitu perlindungan hukum yang bertujuan untuk mencegah terjadinya suatu sengketa;

b. Perlindungan hukum Represif yaitu perlindungan hukum yang bertujuan menyelesaikan sengketa. ${ }^{29}$

Perlindungan hukum bagi kreditur dalam kondisi tersebut diperlukan manakala terjadi wanprestasi oleh debitur. Menurut Subekti, wanprestasi (kelalaian atau kealpaan) seorang debitur dapat berupa empat macam, yaitu:

a. tidak melakukan apa yang disanggupi akan dilakukannya;

b. melaksanakan apa yang dijanjikannya tetapi tidak sebagaimana yang dijanjikannya;

c. melaksanakan apa yang dijanjikannya, tetapi terlambat; dan

d. melakukan sesuatu perbuatan, yang menurut perjanjian tidak boleh dilakukan. ${ }^{30}$

Menurut M. Yahya Harahap bahwa "wanprestasi" dapat dimaksudkan juga sebagai pelaksanaan kewajiban yang tidak tepat pada waktunya atau dilaksankan tidak selayaknya. ${ }^{31} \mathrm{Hal}$ ini mengakibatkan apabila salah satu pihak tidak memenuhi atau tidak melaksanakan isi perjanjian yang telah mereka sepakati atau yang telah mereka buat maka yang telah melanggar isi perjajian tersebut telah melakukan perbuatan wanprestasi.

Wanprestasi memberikan akibat hukum terhadap pihak yang melakukannya dan membawa konsekuensi terhadap timbulnya hak pihak yang dirugikan untuk menuntut pihak yang melakukan wanprestasi untuk memberikan ganti rugi, sehingga

28 Sudikno Mertokusumo, Mengenal Hukum (Suatu Pengantar), Yogyakarta: Liberty, 1991, hlm. 38.

29 Philipus M. Hadjon, Perlindungan Hukum Bagi Rakyat di Indonesia, Surabaya: Bina Ilmu, 1998, hlm. 84.

30 R. Subekti, Hukum Perjanjian, Jakarta: Intermasa, 2002, hlm. 45.

31 M.Yahya Harahap, Segi-Segi Hukum Perjanjian, Bandung: Alumni, 1982, hlm. 60. 
oleh hukum diharapkan agar tidak ada satu pihak pun yang dirugikan karena wanprestasi tersebut.

Untuk memberikan perlindungan hukum secara preventif atas resiko terjadi hapusnya obyek hak tanggungan maka dalam hal ini kreditur harus berpikir secara visioner pada saat hendak melakukan perjanjian kredit. Dalam perjanjian tersebut dapat dimasukkan klausul mengenai penggantian obyek jaminan dengan benda lainnya milik debitur apabila terjadi hapusnya hak atas obyek jaminan yang dibebani hak tanggungan. Adanya klausul dalam perjanjian pokok tersebut dapat menjadi sarana untuk mencegah terjadinya permasalahan atau dengan kata lain dapat memberikan perlindungan hukum secara preventif bagi debitur.

$$
\text { Selanjutnya mengenai bentuk }
$$
perlindungan hukum secara represif dapat didasarkan pada jaminan umum yang disebutkan dalam Pasal 1131 BW. Jaminan umum seperti itu diberikan kepada setiap Kreditur yang berhak atas seluruh harta kekayaan Debitur sebagaimana telah dijelaskan diatas. Maka upaya hukum yang bisa dilakukan oleh Kreditur yang tidak lagi mempunyai hak preferent terhadap jaminan apabila Debitur wanprestasi, dan Kreditur dapat mengajukan permohonan eksekusi kepada pengadilan melalui gugatan biasa.

Untuk menentukan kapan seseorang telah melalaikan kewajibannya dapat dilihat dari isi perjanjian. Dalam perjanjian biasanya diatur kapan seseorang harus melaksanakan kewajibannya, seperti menyerahkan sesuatu barang atau melakukan suatu perbuatan. Apabila dalam perjanjian tidak disebutkan kapan seseorang harus menyerahkan sesuatu atau berbuat sesuatu, maka sebelum mengajukan gugatan wanprestasi seorang kreditur harus memberikan somasi atau surat peringatan yang menyatakan bahwa kreditur telah lalai dan agar memenuhi kewajibannya dalam jangka waktu tertentu (Pasal 1238). Apabila prestasi yang diperjanjikan adalah untuk tidak melakukan suatu perbuatan, maka tidak diperlukan somasi. Hal ini karena begitu debitur melakukan perbuatan yang dilarang, maka dia telah melakukan wanprestasi. ${ }^{32}$ Menurut Moch. Isnaeni, pihak yang dirugikan dapat mengajukan gugat ke pengadilan bersamaan dengan permohonan peletakan sita jaminan terhadap harta pihak yang melakukan wanprestasi. Berdarkan gugatan tersebut apabila diputuskan bahwa pihak yang wanprestasi terbukti bersalah maka wajib untuk memenuhi isi putusan hakim yang sudah in kracht yakni membayar ganti rugi. ${ }^{33}$

\section{Pasal 1243 BW menentukan :} "Penggantian biaya, rugi, dan bunga karena tidak dipenuhinya suatu perikatan, barulah mulai diwajibkan, apabila si berutang, setelah dinyatakan lalai memenuhi perikatannya, tetap melalaikannya atau jika sesuatu yang harus diberikan atau dibuatnya, hanya dapat diberikan dan dibuat dalam tenggang waktu yang telah dilampaukannya".

Berdasarkan pasal ini, ada dua cara penentuan titik awal penghitungan ganti kerugian, yaitu sebagai berikut:

a. Jika dalam perjanjian itu tidak ditentukan jangka waktu, pembayaran ganti kerugian

\footnotetext{
32 Akhmad Budi Cahyono dan Surini Ahlan Sjarif, Mengenal Hukum Perdata, Depok: Gita Tama, 2008, hlm. 45.

33 Moch. Isnaeni, Lembaga Jaminan Kebendaan Dalam Burgerlijk Wetboek: Gadai Dan Hipotek, Revka Petra Media, 2016, hlm. 5
} 
mulai dihitung sejak pihak tersebut telah dinyatakan lalai, tetapi tetap melalaikannya.

b. Jika dalam perjanjian tersebut telah ditentukan jangka waktu tertentu pembayaran ganti kerugian mulai dihitung sejak terlampauinya jangka waktu yang telah ditentukan tersebut. ${ }^{34}$

Apabila dengan adanya putusan pengadilan yang sudah berkekuatan hukum tetap diabaikan oleh debitur, maka lembaga peletakan sita jaminan akan segera diproses, yaitu dengan menjual segenap harta pihak yang dinyatakan bersalah guna melunasi kerugian yang dialami oleh kreditur.

\section{Penutup}

\subsection{Kesimpulan}

Hapusnya obyek Hak Tanggungan sebagai perjanjian kebendaan mempunyai akibat hukum, yaitu berubahnya posisi Kreditur, yang semula berkedudukan sebagai Kreditur preferent yang mempunyai hak kebendaan kemudian berkedudukan sebagai kreditur konkurent yang mempunyai hak perseorangan. Kondisi tersebut membuat Kreditur mempunyai persamaan hak dan persamaan kedudukan dengan Kreditur lainnya terhadap harta seorang Debitur sehingga dalam pemenuhan piutangnya tidak dapat didahulukan pembayarannya sekalipun di antara mereka ada yang mempunyai tagihan yang lahir terlebih dulu dari pada yang lain.

Perlindungan hukum bagi Kreditur atas hapusnya obyek hak tanggungan dapat diperoleh secara preventif melalui perjanjian dengan memasukkan klausul mengenai penggantian obyek jaminan dengan benda lainnya milik debitur apabila terjadi hapusnya hak atas obyek jaminan yang dibebani hak tanggungan. Sedangkan perlindungan hukum secara represif dapat diperoleh kreditur dengan mengajukan gugat ke pengadilan bersamaan dengan permohonan peletakan sita jaminan terhadap harta pihak yang melakukan wanprestasi.

\subsection{Saran}

Diperlukan adanya regulasi yang secara tegas mampu memberikan perlindungan hukum bagi kreditur dalam perjanjian jaminan khususnya terhadap kondisi kemungkinan terjadi hapusnya obyek hak tanggungan sehingga mampu memberikan rasa aman baik bagi kreditur maupub debitur dalam pelaksanaan perjanjian kredit.

\section{DAFTAR PUSTAKA}

Abdul R. Saliman, Hukum Bisnis Untuk Perusahaan Teori dan Contoh Kasus, Jakarta: Kencana, 2010.

Adrian Sutedi, Peralihan Hak Atas Tanah dan Pendaftarannya, Jakarta: Sinar Grafika, 2010.
Ahmadi Miru dan Sakka Pati, Hukum Perikatan Penjelasan Makna Pasal 1233 Sampai 1456 BW, Jakarta: Rajagrafindo Persada, 2008.

Akhmad Budi Cahyono dan Surini Ahlan Sjarif, Mengenal Hukum Perdata, Depok: Gita Tama, 2008.

\footnotetext{
34 Ahmadi Miru dan Sakka Pati, Hukum Perikatan Penjelasan Makna Pasal 1233 Sampai 1456 BW, Jakarta: Rajagrafindo Persada, 2008, hlm. 13.
} 
Boedi Harsono, Hukum Agraria Indonesia, Sejarah Pembentukan Undang-Undang Pokok Agraria, Isi dan Pelaksanaannya, Jakarta: Djambatan, 2000.

Christian Liongan, "Penyelesaian Pembagian Harta Perkawinan Bagi WNI Keturunan Tionghoa Setelah Berlakunya Undang-Undang Nomor 1 Tahun 1974 Tentang Perkawinan Di Kota Manado, Sulawesi Utara", Tesis, Semarang: Program Pasca Sarjana, Universitas Diponegoro, 2007.

Djuhaendah Hasan, Lembaga Jaminan Kebendaan Bagi Tanah dan Benda Lain yang Melekat pada Tanah dalam Konsepsi Penerapan Asas Pemisahan Horizontal, Bandung: Citra Aditya Bakti, 1996.

Gatot Supramono, Perbankan dan Masalah Kredit, Jakarta: Rineka Cipta, 2009.

Hatta Isnaini Wahyu Utomo, "Hukum Jaminan", Bahan Ajar, Surabaya: Fakultas Hukum Universitas Yos Sudarso, 2017.

Herowati Poesoko, Parate execcutie Obyek Hak Tanggungan (inkonsistensi, Konflik Norma dan Kesesatan Penalaran dalam UUHT), Yogyakarta: LaksBang PRESSind, 2008.

Irma Devita Purnamasari, Hukum Jaminan Perbankan, Bandung: Mizan Pustaka, 2011.

J.Satrio, Hukum Jaminan,Hak Jaminan Kebendaan Hak Tanggungan, Bandung: Alumni, 1997.

Kartini Muljadi dan Gunawan Widjaja, Seri Hukum Harta Kekayaan: Hak Tanggungan, Jakarta: Prenada Media, 2004

Kasmir, Pemasaran Bank, Jakarta: Prenada Media, 2005.

M.Yahya Harahap, Segi-Segi Hukum Perjanjian, Bandung: Alumni, 1982.

Man S. Sastrawidjaja, Hukum Kepailitan dan Penundaan Kewajiban Pembayaran Utang, Bandung: Alumni, 2014.

Mariam Darus Badrulzaman, Bab-bab Tentang Credietverband, Gadai dan Fidusia, Bandung: Alumni, 1987.
Mariam Darus Badrulzaman, Bab-Bab Tentang Credietverband, Gadai, Fidusia, Bandung: Alumni, 1987.

Moch. Isnaeni, Lembaga Jaminan Kebendaan Dalam Burgerlijk Wetboek : Gadai Dan Hipotek, Surabaya: Revka Petra Media, 2016.

-----, Pengantar Hukum Jaminan Kebendaan, Surabaya: Revka Petra Media, 2016.

Philipus M. Hadjon, Perlindungan Hukum Bagi Rakyat di Indonesia, Surabaya: Bina IImu, 1998.

Purwahid Patrik, Hukum Jaminan, Edisi Revisi dengan UUHT, Semarang: Fakultas Hukum Universitas Diponegoro, 1989.

R. Subekti, Hukum Perjanjian, Jakarta: Intermasa, 2002.

Jaminan-jaminan Untuk Pemberian Kredit Menurut Hukum Indonesia, Bandung: Citra Aditya Bakti, 1991.

Rachmadi Usman, Aspek-aspek Hukum Perbankan di Indonesia, Jakarta: Gramedia Pustaka Utama, 2001.

Sri Soedewi Masjchoen Sofwan, Hukum Jaminan di Indonesia: Pokok-Pokok Hukum Jaminan dan Jaminan Perorangan, Yogyakarta: Liberty, 1980.

Sudikno Mertokusumo, Mengenal Hukum (Suatu Pengantar), Yogyakarta: Liberty, 1991.

Sutan Remy Sjahdeini, Hak Tanggungan - AsasAsas, Ketentuan Pokok dan Masalah Yang Dihadapi Oleh Perbankan, Bandung: Alumni, 1999.

Sutan Remy Sjahdeini, Hukum Kepailitian, Jakarta: Grafiti, 2010.

Trisadini Prasastinah Usanti, dan Leonora Bakarbessy, Buku Referensi Hukum Perbankan Hukum Jaminan, Surabaya: Revka Petra Media, 2016.

Try Widiyono, Agunan Kredit Dalam Financial Engineering, Jakarta: Ghalia Indonesia, 2009. 